\title{
A New Isolation and Purification Method for Staphylococcal Protein A Using Membrane Encapsulated Rabbit IgG-Agarose
}

\author{
Akiyoshi Sakoda and Henry Y. Wang \\ Department of Chemical Engineering, University of Michigan, Ann Arbor, \\ Michigan 48109
}

Accepted for publication February 15, 1989

\begin{abstract}
A new isolation and purification method for bioproducts using membrane-encapsulated affinity adsorbents was investigated. The new method involves encapsulation of affinity adsorbents, batch adsorption of the bioproduct from whole fermentation broth and rapid batch desorption after dissolution of the capsule membranes. Recovery of protein A from Staphylococcus aureus was used as the model experimental system. Affinity adsorbents such as rabbit IgG-agarose were successfully encapsulated within calcium alginate membranes and used directly to recover protein $A$ from whole cell homogenate containing a number of macromolecular contaminants as well as suspended solids. Both high yield and high purity of protein $A$ were recovered by this method in comparison with various previously reported methods.
\end{abstract}

\section{INTRODUCTION}

There has been much recent interest in the application of affinity adsorption in bioseparation processes. The high selectivity of biospecific ligands makes affinity adsorption especially attractive for isolation and purification of native and recombinant proteins and polypeptides from culture broths. Ideally, the use of affinity adsorption in early stages of downstream processing can be expected to significantly increase the final bioproduct yield. Although a number of investigators have reported the successful use of affinity chromatography for purification of various bioproducts, affinity adsorption is still primarily used at the final purification stage of a separation process and to purify small quantities of a bioproduct from relatively clean solutions free of suspended solids. ${ }^{1}$ Conventional solids separation methods such as centrifugation and filtration are often inefficient in removing suspended solids and colloids from whole culture broth. ${ }^{2}$ When chromatographic grade affinity adsorbents are used directly in batch adsorption from whole broths, fouling or pore blockage of the adsorbent often occur because of adhesion of suspended solids or nonspecific adsorption of macromolecules onto the adsorbent surface. Also, the size of such adsorbents, usually
$50-100 \mu \mathrm{m}$ diameter, is generally too small to allow easy recovery from the viscous broth.

The idea of using affinity adsorbents in combination with aqueous two-phase extraction ${ }^{3,4}$ at the whole broth stage has been proposed recently to circumvent these problems. Affinity adsorbents with the adsorbed bioproduct are recovered from the broth by two-phase partitioning, since the adsorbents move to one phase while contaminants such as cell debris move to the other phase. Problems associated with reagent costs may occur when using this technique for large scale processing. Using immobilized adsorbents by entrapping chromatographic grade ion exchange resins inside various hydrogel beads or capsules of $1-4 \mathrm{~mm}$ diameter may offer several advantages, including reduced susceptibility of adsorbents to fouling. ${ }^{2,5}$

Our approach using membrane encapsulated affinity adsorbents for whole broth processing proposed and investigated in this work is illustrated in Figure 1. First of all, affinity adsorbents are encapsulated within hydrogel membrane capsules which have well-defined characteristics such as size, membrane thickness, and pore size. Encapsulated adsorbents are then used in batch adsorption from whole cell homogenate. When adsorption is completed, the encapsulated adsorbents can easily be recovered by screening or other techniques and washed to remove various contaminant macromolecules and debris. Desorption of a desired bioproduct can be carried out with or without dissolving the capsule membranes. After desorption, the adsorbents can be reused without significant changes of the adsorption properties.

The advantages of this concept can be explained as follows: The membrane encapsulated adsorbents that are placed in the whole broth allow a desired bioproduct to preferentially diffuse through the capsule membranes but reject the permeation of various macromolecular contaminants and suspended solids. Therefore, the adsorbents can be protected against nonspecific adsorption and contamination by other macromolecular proteins and various sus- 


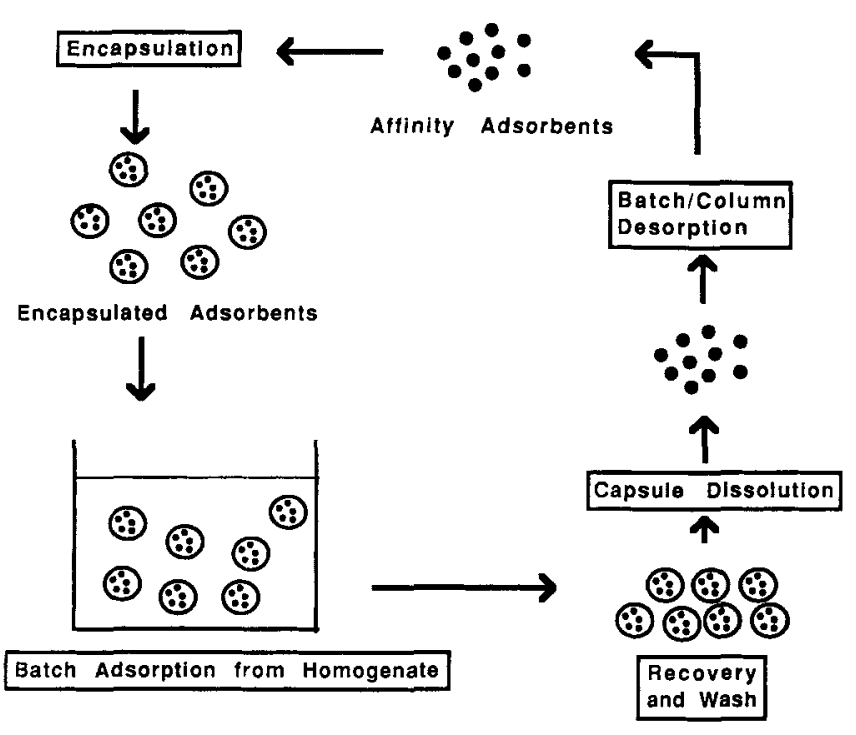

Figure 1. Bioproduct recovery process using encapsulated affinity adsorbents at whole broth stage.

pended solids. The capsules may also protect the adsorbents from mechanical damage due to handling and stirring during processing. The size of the capsules can now be designed to be large enough for easy and complete recovery from the whole broth without undergoing additional filtration or centrifugation. Since the capsule membranes can be easily dissolved, rapid desorption after releasing the adsorbents from the capsules can be carried out, and the adsorbents can be easily encapsulated again for reuse.

The model experimental system chosen for this investigation is the direct recovery of Staphylococcal protein A $(\mathrm{SpA})$ from whole cell homogenate using rabbit IgG-agarose encapsulated inside calcium alginate membranes. Staphylococcal Protein A is a cell wall protein produced by the bacterium Staphylococcus aureus and is biospecifically reactive with the $F_{r}$ region of various immunoglobulin species without interacting at their antigenic sites. Immobilized protein $\mathrm{A}$ has been shown to bind with different immunoglobulin species to a varying degree ${ }^{6,7,8}$ Protein A labeled with a tracer group can be used to detect and quantify antibodies and antigens. Also, protein A immobilized onto a solid support can be used for the purification of antibodies, cell separation, etc. ${ }^{8,9}$ Some physicochemical properties of protein A were described by Bjork and co-workers. ${ }^{10}$ The conventional separation process of protein A is quite complex and involves multiple steps. The initial step is usually lysostaphin digestion of the bacterial cells to solubilize the cell wall Protein A. " Subsequent processing involves centrifugation to remove solids, acid precipitation, filtration or a second centrifugation, ion-exchange chromatography, and affinity chromatography. ${ }^{7,12}$ Generally speaking, this multi-step separation process is time consuming and results in low overall product yield.

The objective of this work is to investigate the feasibility of a new separation scheme for protein $\mathrm{A}$ isolation and purification using the encapsulated IgG-agarose within calcium alginate membranes as shown in Figure 1.

\section{MATERIALS AND METHODS}

\section{Materials}

Staphylococcus aureus, Cowan I, (ATCC No. 12598) was obtained from American Type Culture Collection. The following chemicals were purchased from Sigma (St. Louis, MO): rabbit IgG-agarose, protein A, lysostaphin, DNAse, dextran (molecular weight of $42.6 \times 10^{3}$ ), HEPES, and Tween 20. Sodium alginate, trade name Kelco Gel LV, was obtained from Kelco (Chicago, IL). Other chemicals used were of research grade.

\section{Preparation of Cell Homogenate}

Staphylococcus aureus was grown as described in the literature. ${ }^{12}$ The culture medium was comprised of $14.3 \mathrm{~g} / \mathrm{L}$ trypticase soy broth, $5.67 \mathrm{~g} / \mathrm{L}$ yeast extract, $5.67 \mathrm{~g} / \mathrm{L}$ glucose, and $5.67 \mathrm{~g} / \mathrm{L}$ tri-(hydroxymethyle)-aminomethane in distilled water. The culture was grown for $10 \mathrm{~h}$ at $37^{\circ} \mathrm{C}$. Cells were harvested by centrifugation at $4^{\circ} \mathrm{C}$ and washed three times with $25 \mathrm{~m} M$ HEPES buffer ( $\mathrm{pH} 7.2$ ).

About $30 \mathrm{~mL}$ of thus obtained bacterial cell paste was resuspended in $300 \mathrm{~mL}$ of $25 \mathrm{~m} M$ HEPES containing $145 \mathrm{~m} M$ sodium chloride $(\mathrm{pH} 7.5)$ and heated to $37^{\circ} \mathrm{C}$, shaking slowly. After this suspension reached $37^{\circ} \mathrm{C}, 0.75 \mathrm{mg} / \mathrm{L}$ lysostaphin and $0.15 \mathrm{mg} / \mathrm{L}$ DNAse were added, and the mixture was slowly shaken for $3 \mathrm{~h}$ at $37^{\circ} \mathrm{C}$. Thus obtained homogenate was stored at $-30^{\circ} \mathrm{C}$. Concentrations of protein $\mathrm{A}$, contaminant proteins and suspended solids in the homogenate were estimated to be 108,1170 , and $1300 \mathrm{mg}$ dry $w t / L$, respectively. Assay procedures are described later.

\section{Encapsulation of Rabbit IgG-Agarose}

Precise dosages of rabbit IgG-agarose were suspended in $25 \mathrm{~m} M$ HEPES buffer containing $0.5 \%(\mathrm{w} / \mathrm{v})$ calcium chloride and $20 \%(\mathrm{w} / \mathrm{v})$ dextran (pH 7.2). Dextran was used as a viscosity enhancer. ${ }^{13}$ Droplets of this suspension were introduced into $0.5 \%(\mathrm{w} / \mathrm{v})$ sodium alginate solution in $25 \mathrm{~m} M$ HEPES buffer ( $\mathrm{pH} 7.2$ ). The adsorbents were instantaneously wrapped inside a calcium alginate gel membrane due to rapid crosslinking of the anionic polymer, alginate, with divalent calcium cations. Capsules containing IgG-agarose were recovered from the alginate solution, washed three times with $10 \mathrm{~m} M$ HEPES ( $\mathrm{pH} 7.2)$ and subsequently placed in $10 \mathrm{~m} M$ HEPES buffer containing $0.5 \%$ $(\mathrm{w} / \mathrm{v})$ calcium chloride $(\mathrm{pH}$ 7.2) for 10 min to shrink and harden the capsule membranes. Encapsulated adsorbents thus prepared were stored in the HEPES buffer containing $0.15 \mathrm{M}$ sodium chloride $(\mathrm{pH} 7.2)$ at $4^{\circ} \mathrm{C}$ until use. The size of capsules could be varied by using a droplet generator similar to the one described by Klein and co-workers. ${ }^{14}$ Effective diffusivity of protein $\mathrm{A}$ in $0.5 \%$ calcium alginate gel was experimentally determined using gel beads in a similar manner to that described in the literature. ${ }^{15}$ 


\section{Adsorption}

Adsorption equilibrium of protein A from protein A solutions onto free IgG-agarose and from cell homogenates onto encapsulated IgG-agarose were obtained through batch adsorption studies. We examined the effects of the encapsulation and the presence of various contaminants and cell debris in the homogenate on the adsorption capacity of IgG-agarose. In the case of free IgG-agarose, $0.1-$ $0.5 \mathrm{~mL} \mathrm{IgG-agarose}$ were directly added into $5 \mathrm{~mL}$ of $100-200 \mu \mathrm{g} / \mathrm{mL}$ protein A solutions prepared by using $25 \mathrm{~m} M$ HEPES buffer ( $\mathrm{pH} 7.2$ ). In the case of encapsulated IgG-agarose, $2 \mathrm{~mL}$ capsules containing $0.1-0.5 \mathrm{~mL}$ IgGagarose were added into $5 \mathrm{~mL}$ cell homogenate prepared as previously described. The suspensions were well stirred on a rotator in a constant temperature room at $4^{\circ} \mathrm{C}$ for over $12 \mathrm{~h}$. Initial and final equilibrium protein A concentrations were measured as described later. Initial and final concentrations of contaminant proteins were also measured.

\section{Recovery and Wash of Encapsulated Adsorbents}

Encapsulated adsorbents were recovered from the suspensions using a stainless steel mesh and washed with $10 \mathrm{~mL}$ of $10 \mathrm{~m} M$ HEPES buffer ( $\mathrm{pH} 7.2$ ). The protein A concentration in the solution used for washing was also determined.

\section{Desorption}

Sodium citrate solution $5 \mathrm{~mL}$ of $1 \%(\mathrm{w} / \mathrm{v})$ was added to dissolve $2 \mathrm{~mL}$ of the recovered and wasied capsules containing IgG-agarose. After the complete dissolution of capsule membranes and sedimentation of the adsorbents, the protein A concentration in the discarded supernatant was measured. Afterwards $5 \mathrm{~mL}$ of $0.1 M$ glycine containing $0.5 M$ sodium chloride $(\mathrm{pH} 2.5)$ at $4^{\circ} \mathrm{C}$ was added to release the protein $\mathrm{A}$. The suspension was shaken on a rotator in a constant temperature room at $4^{\circ} \mathrm{C}$ for over $12 \mathrm{~h}$. Final protein A concentration was determined.

\section{Protein A Assay}

Protein A was assayed by a competitive ELISA method using protein A-peroxidase conjugate according to the procedure described by Considine and co-workers ${ }^{16}$ with some modifications. Orthophenylenediamine and hydrogen peroxide concentrations were $1 \mathrm{mg} / \mathrm{ml}$ and $0.03 \%$, respectively. All the samples for protein $\mathrm{A}$ assay were diluted precisely $1 / 10-1 / 100$ with $10 \mathrm{~m} M \mathrm{Na}_{2} \mathrm{HPO}_{4} / \mathrm{NaH}_{2} \mathrm{PO}_{4}$ buffer containing $0.2 M$ sodium chloride and $0.1 \%(\mathrm{v} / \mathrm{v})$ Tween $20(\mathrm{pH} \mathrm{7.2)}$ so that protein A concentration was below $2 \mu \mathrm{g} / \mathrm{mL}$.

\section{Protein Assay}

Concentration of contaminant proteins was determined by Bradford Protein Assay ${ }^{17}$ using human serum albumin as the standard.

\section{RESULTS AND DISCUSSION}

\section{Encapsulation of Affinity Adsorbents}

Basic approaches for encapsulation of bioactive materials, including affinity adsorbents, developed in our laboratory are described elsewhere with several examples of applications. ${ }^{2,13}$ The main advantages of our encapsulation approaches are 1) the procedure of encapsulation has been simplified, 2) materials to be encapsulated do not come into contact with the gel-forming polymers, and 3 ) capsule membrane characteristics can be controlled. This suggests that our approach may be suitable for large-scale encapsulation and processing of bioactive materials including affinity adsorbents.

Making good spherical capsules with uniform size and membrane thickness is important, as it is in other applications. Particularly in the case of encapsulating adsorbents for downstream processing, we need to know the effective diffusivity of the desired protein product in the capsule membranes. In other words, capsule membranes should be designed to have pores large enough for the passages of the specific protein molecules. Effective diffusivities of glucose, ethanol and proteins in calcium alginate gel have been investigated by various researchers ${ }^{14,15,18-20}$ and it is known that the effective diffusivities are significantly dependent on the concentration of sodium alginate and may vary with the source and the lot of the sodium alginate preparations. Figure 2 shows the diffusion of protein A into the calcium alginate beads prepared from a $0.5 \%$ $(\mathrm{w} / \mathrm{v})$ sodium alginate solution. Solid lines in Figure 2 represent the theoretical profiles ${ }^{21}$ given by eqs. (1)-(3), when the effective diffusivity in the gel beads, $D_{e}$, is the same as that in bulk solution, $D_{w}$, and when the value of the effective diffusivity is only one-third of the bulk value. The latter seems to fit the experimental data more accurately.

$$
\frac{C}{C_{0}}=\frac{\alpha}{1+\alpha}\left\{1+\sum_{n=1}^{\infty} \frac{6(1+\alpha) \exp \left(-D_{e} q_{n}^{2} t / R_{b}^{2}\right)}{9+9 \alpha+q_{n}^{2} \alpha^{2}}\right\}
$$

where $\alpha=V_{s} / V_{b}, V_{s}$ and $V_{b}$ represent the volume of protein A solution and gel bead respectively, and $q_{n}$ terms are the roots of eq. (2):

$$
\tan q_{n}=3 q_{n} /\left(3+\alpha q_{n}^{2}\right)
$$

All beads used were assumed to be spherical and the mean radius of the beads, $R_{b}$, were determined from eq. (3)

$$
V_{b}=4 \pi R_{b}^{3} N / 3
$$

where $N$ is the number of beads used.

We can prepare membranes with larger pores in order to reduce the diffusion resistance in the membrane by decreasing the sodium alginate concentration or by employing different sources of alginate preparations. However, the mechanical strength of the capsules prepared using less than $0.5 \%(\mathrm{w} / \mathrm{v})$ sodium alginate solutions was not strong 


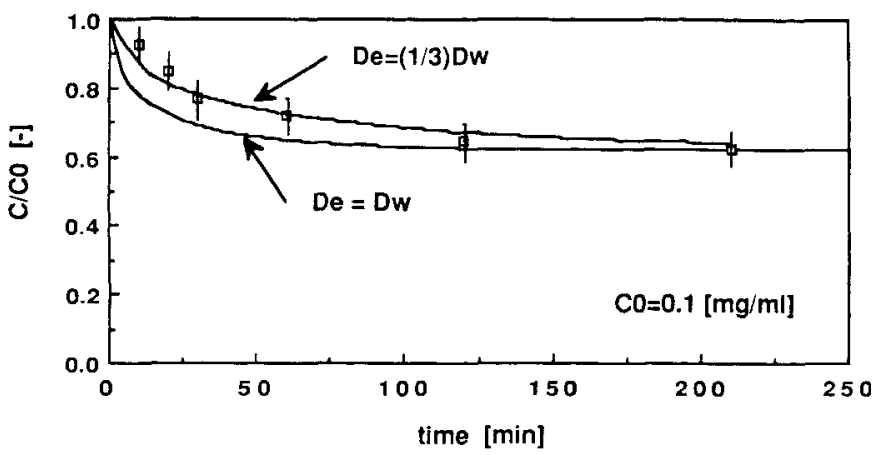

Figure 2. Diffusion of protein $A$ into calcium alginate gel beads where $C$ is the concentration of protein $\mathrm{A} ; C_{0}$ is the initial concentration; $D_{e}$ is the effective diffusivity in the gel; and $D_{w}$ is the diffusivity in bulk.

enough to withstand mechanical stress due to stirring. Because of this, rabbit IgG-agarose were encapsulated within hydrogel membranes prepared from $0.5 \%(\mathrm{w} / \mathrm{v})$ sodium alginate solution. A picture of the prepared encapsulated IgG-agarose is shown in Figure 3.

\section{Adsorption of Protein A}

Figure 4 gives adsorption equilibrium of protein $\mathrm{A}$ with IgG-agarose at $4^{\circ} \mathrm{C}, \mathrm{pH} 7.2$. The amount of protein $\mathrm{A}$ adsorbed onto the IgG-agarose was evaluated based on the following equation:

$$
q=\left[C_{0} V_{s}-C_{\infty}\left(V_{s}+V_{a}+V_{c}\right)\right] / V_{a}
$$

where $q$ is the amount adsorbed in equilibrium with the final concentration; $C_{\infty}, C_{0}$ is the initial concentration; and $V_{s}, V_{a}$ and $V_{c}$ are the volumes of a protein A solution or the cell homogenate, IgG-agarose, and the void in capsules respectively. $V_{a}+V_{c}$ represents the total volume of the capsules containing IgG-agarose. For free $\operatorname{IgG}, V_{c}$ is equal to 0 .

Open square symbols represent the adsorption from protein A solutions onto free IgG-agarose, and the solid square symbols represent the adsorption data from the cell homogenate using encapsulated IgG-agarose. As shown in Figure 4, the adsorption capacity in both cases is approximately $1 \mathrm{mg} / \mathrm{mL}$ (IgG-agarose gel) regardless of the adsorbent preparations or the sources of the protein A. Thus, the encapsulation process does not harm the rabbit IgG ligand, and the adsorption capacity of the encapsulated adsorbents is not reduced when they are used directly in the cell homogenate. Also, it should be noted that the shape of the isotherm belongs to the so-called rectangular isotherm indicating nearly complete recovery of protein A by batch adsorption is possible. Nonspecific adsorption of protein $A$ onto capsules not containing IgG-agarose was not experimentally observed. Figure 5 indicates that $12 \mathrm{~h}$ is sufficient for obtaining adsorption equilibrium data.

Figure 5 shows adsorption profiles of protein $\mathrm{A}$ from the cell homogenate using three different membrane encapsulated rabbit IgG-agarose of various sizes. Rapid adsorption (solid square symbols) was observed when $0.5 \mathrm{~mL}$ free IgG-agarose was placed into $5 \mathrm{~mL}$ cell homogenate. Adsorption profiles represented by open square and triangle

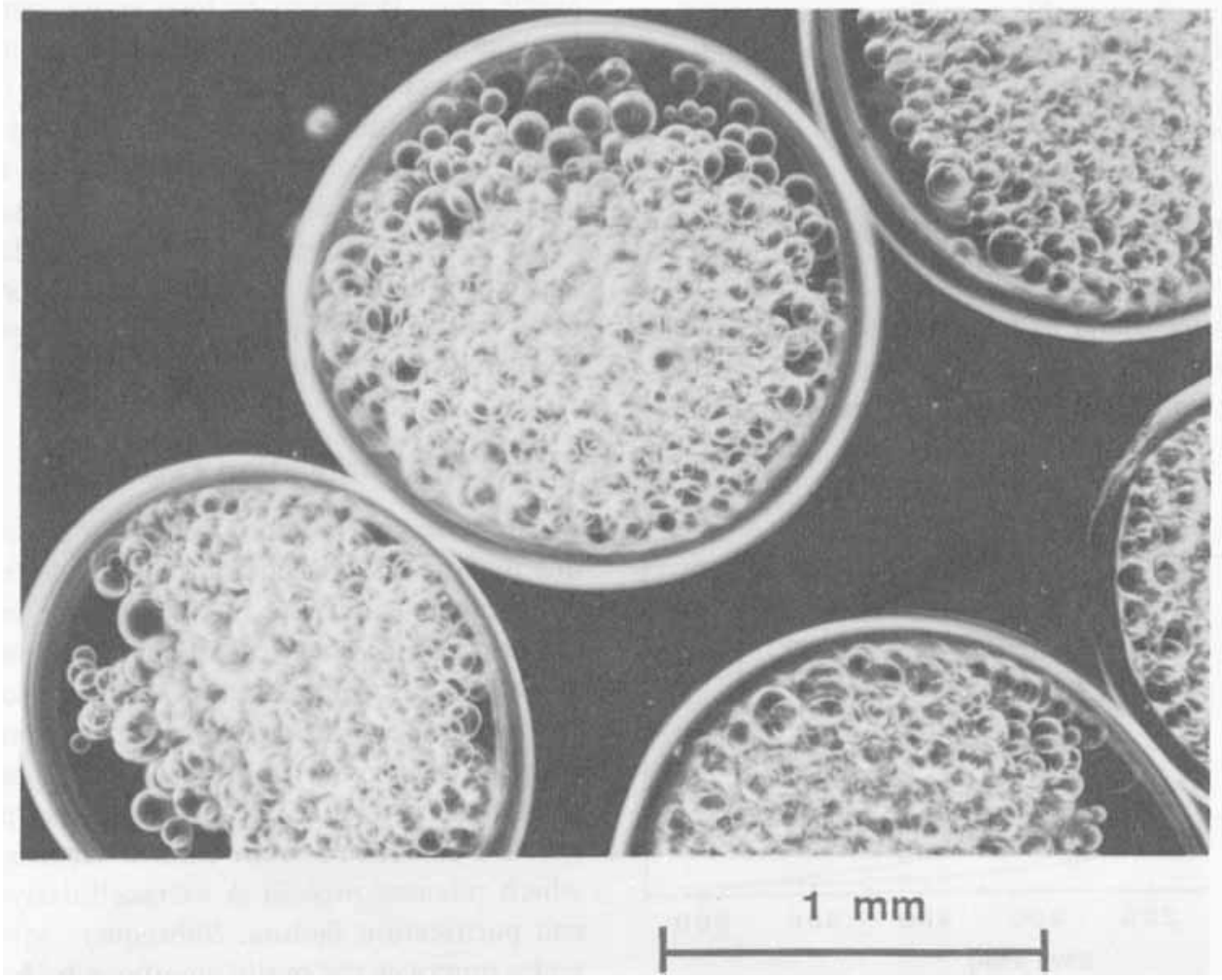

Figure 3. Encapsulated rabbit IgG-agarose. 


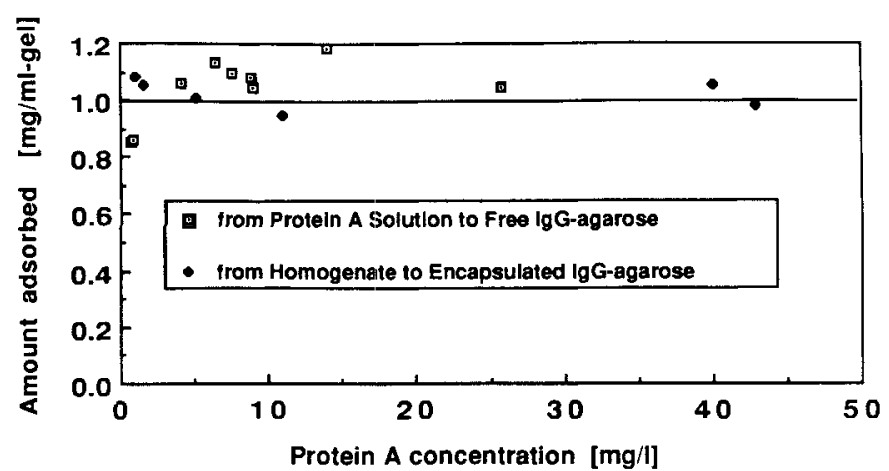

Figure 4. Adsorption capacity of free and encapsulated IgG-agarose.

symbols in Figure 5 were observed when $2 \mathrm{~mL}$ capsules containing $0.5 \mathrm{~mL} \mathrm{IgG-agarose,} \mathrm{of} \mathrm{sizes} 1$ and $2 \mathrm{~mm}$ in diameter, respectively, were placed into $5 \mathrm{~mL}$ cell homogenate. The adsorption rate of protein A onto encapsulated adsorbents was found to be dependent on the capsule size. Therefore, the adsorption rate is most likely controlled by the diffusion inside the capsule including the capsule membrane. Generally, the smaller the size of the capsule, the faster the adsorption rate was experimentally observed. However, for the sake of easy recovery of the encapsulated adsorbents from the cell homogenate, the minimum size of the capsule is considered to be ca. $0.5 \mathrm{~mm}$ diameter. Contribution of the diffusion resistance inside the IgG-agarose gel to overall mass transfer resistance may not be negligible either. Additional theoretical analysis is currently being conducted in our laboratory to clarify this issue. The most important point is that the time of the adsorption step is dominant in this complete process and that the time is approximately a few hours, which is considered to be acceptable in comparison with other conventional multi-step processes. ${ }^{7,12}$

\section{Desorption of Protein A and Cyclic Use of lgG-Agarose}

Two minutes were found to be adequate for dissolving the capsule membranes completely using $1 \%(\mathrm{w} / \mathrm{v})$ sodium citrate solution. Also, desorption of protein A using

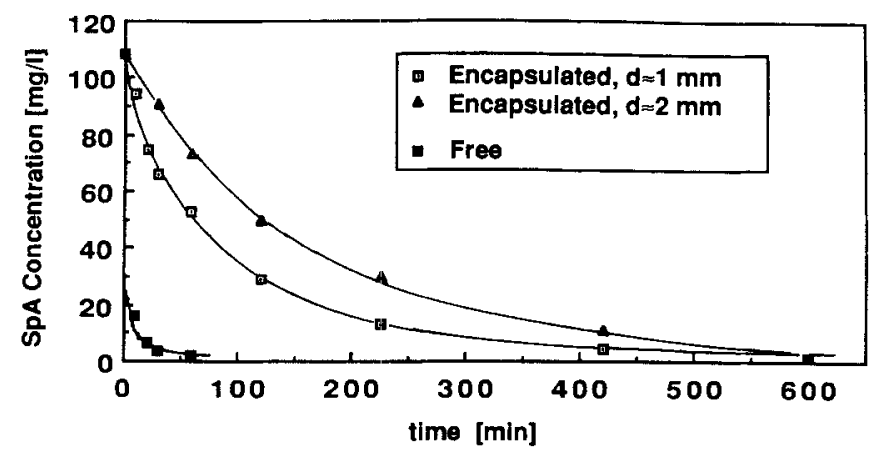

Figure 5. Adsorption rate to free and encapsulated IgG-agarose.

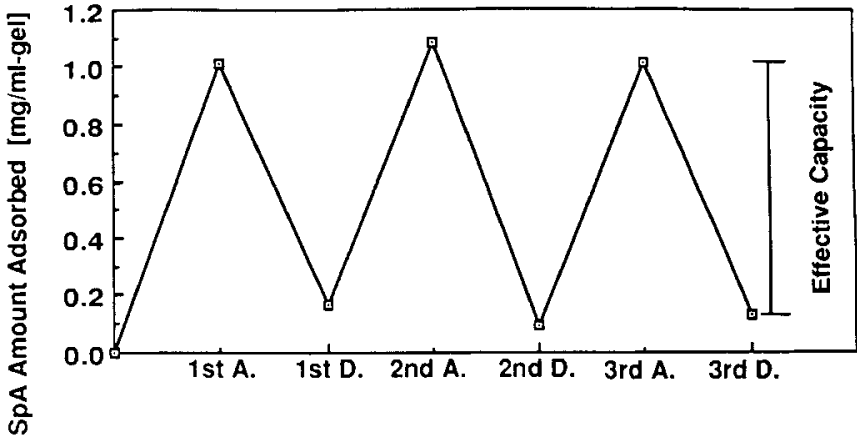

Figure 6. Change of the amount adsorbed of protein A during cyclic adsorption and desorption.

$0.1 M$ glycine containing sodium chloride $(\mathrm{pH} 2.5)$ could be achieved in only $10 \mathrm{~min}$. The average amount of desorbed protein A was ca. $900 \mu \mathrm{g} / \mathrm{mL}$ gel, which corresponds to nearly $90 \%$ of the total adsorbed product, and that of contaminant proteins was approximately $30 \mu \mathrm{g} / \mathrm{mL}$ gel. The purification factor defined by the following equation was calculated to be 340 :

$$
\text { Purification factor }=(\mathrm{SpA} / \mathrm{CP}) /\left(\mathrm{SpA}_{0} / \mathrm{CP}_{0}\right)
$$

where $\mathrm{SpA}$ and $\mathrm{CP}$ are the concentration of protein $\mathrm{A}$ and contaminant proteins, respectively. Subscript 0 represents the initial concentrations in the cell homogenate. Protein A was not detected in the solutions used for washing and dissolving the capsules.

Since $90 \%$ of protein A could be recovered using this method, thi product yield appears to be about $90 \%$ for a single pass. However, as long as we can reuse the adsorbents in a cyclic mode for repeated use $100 \%$ recovery for a single pass may not be required. Plots in Figure 6 represent the amount of protein $A$ recovered by the encapsulated IgG-agarose during multiple cycles of adsorption and desorption. The difference between the higher and the lower values can be regarded as the effective adsorption capacity in repeated adsorption and desorption cycles. No observed decrease in the effective adsorption capacity can be found throughout these cycles.

\section{Yields and Purification Factors}

Yields and purification factors for protein A recovery by this method and various other methods from the literature are compared in Table I. Since a pure protein A solution was used in the study of affinity partitioning using carrier adsorbents (a combination of affinity adsorbents and aqueous two-phase partitioning), a purification factor could not be obtained. Even in such an ideal case, the yield is shown to be only $72 \% .^{22}$ Direct adsorption using nonspecific adsorbents from culture supernatant of a mutant which releases protein A extracellularly gives low yield and purification factors. Subsequent affinity chromatography improves the purity significantly, however, the overall yield is still only $34 \%$. $^{23}$ Table I shows that our ap- 
Table I. Yields and purification factors of protein A by various isolation and purification methods.

\begin{tabular}{|c|c|c|c|c|c|}
\hline Method & Source & & ield & $\mathrm{PF}$ & Reference \\
\hline $\begin{array}{l}\text { Adsorption using encapsulated } \\
\text { affinity adsorbents } \\
\text { (batch desorption) }\end{array}$ & $\begin{array}{l}\text { cell homogenate by } \\
\text { lysostaphin digestion }\end{array}$ & ca. & 100 & ca. 340 & this work \\
\hline $\begin{array}{l}\text { Conventional multistep isolation } \\
\text { including affinity chromatography }\end{array}$ & $\begin{array}{l}\text { cell homogenate by } \\
\text { lysostaphin digestion }\end{array}$ & & $<60$ & NA & 7,12 \\
\hline $\begin{array}{l}\text { Affinity partitioning using } \\
\text { carrier adsorbents } \\
\text { (column elution) }\end{array}$ & protein A solution & & 72 & 一 & 22 \\
\hline $\begin{array}{l}\text { Direct adsorption using } \\
\text { ion-exchange adsorbents }\end{array}$ & $\begin{array}{l}\text { supernatant of culture } \\
\text { media of a mutant }\end{array}$ & & 64 & 7.3 & 23 \\
\hline Affinity chromatography & & & 34 & 554 & 23 \\
\hline
\end{tabular}

proach results in both higher yield and higher purity than these existing methods.

\section{CONCLUSIONS}

A new simple isolation and purification method using membrane encapsulated affinity adsorbents at the whole broth stage was successfully demonstrated for the direct recovery of Staphylococcal protein A from whole cell homogenate. The affinity adsorbent rabbit IgG-agarose was successfully encapsulated within calcium alginate membranes and used in the direct recovery of protein A from cell homogenate. Rapid batch desorption was carried out by dissolving the capsule membranes and the used IgGagarose could be recycled and reused in cyclic mode without considerable decrease in effective adsorption capacity. Both high yield and high purity of protein A from whole cell homogenate were achieved using membrane encapsulated affinity adsorbents.

The authors acknowledge the financial support of the National Science Foundation (grant nos. ECE-86-12969 and CBT-8812996).

\section{References}

1. H. A. Chase, Chem. Eng. Sci., 39, 1009 (1984).

2. S. C. Nigam, A. Sakoda, and H. Y. Wang, Biotechnol. Prog., 4, 166 (1988).
3. P. Hedman and J. G. Gustafsson, Anal. Biochem., 138, 411 (1984).

4. A. K. Frej, J. G. Gustafsson, and P. Hedman, Biochem. Bioeng., 28, 133 (1986).

5. H. Y. Wang and K. Sobnosky, ACS Symp. Ser., 271, 123 (1986).

6. A. Forsgren and J. Sjoquist, J. Immun., 97, 822 (1966).

7. H. Hjelm, K. Hjelm, and J. Sjoquist, FEBS Lett., 28, 73 (1972).

8. J. J. Longone, J. Immunol. Methods, 55, 277 (1982).

9. J. W. Goding, J. Immunol. Methods, 20, 241 (1978).

10. I. Bjork, B. Petersson, and J. Sjoquist, Eur. J. Biochem., 29, 579 (1972).

11. C. A. Schindler and U. T. Schuhardt, Proc. Nat. Acad. Sci., U.S.A., 54, 414 (1964).

12. J. Sjoquist, B. Meloun, and H. Hjelm, Eur. J. Biochem., 29, 572 (1972).

13. S. C. Nigam, I-Fu Tsao, A. Sakoda, and H. Y. Wang, Biotechnol. Techniques, 2, 271 (1988).

14. J. Klein, J. Stock and K. D. Vorlop, Eur. J. Appl. Microb. Biotechnol., 18, 86 (1983).

15. H. Tanaka, M. Matsumura, and I. A. Veliky, Biotechnol. Bioeng., 26, 53 (1984).

16. P. J. Considine, P. Duggan, and A. Eadie, Biosci. Rep., 6, 933 (1986).

17. M. M. Bradford, Anal. Biochem., 72, 248 (1976).

18. M. Kierstan, G. Darcy, and J. Reilly, Biotechnol. Bioeng., 24, 1507 (1982).

19. B. J. M. Hannoun and G. Stephanopoulos, Biotechnol. Bioeng., 28, 829 (1986).

20. G. F. Itamunoala, Biotechnol. Prog., 3, 115 (1987).

21. J. Crank, Chapter 6: "Diffusion in a Sphere" in Mathematics of Diffusion (Clarendon, Oxford, 1956).

22. P. Hedman and J. G. Gustafsson, Anal. NY Acad Sci., 434, 285 (1984)

23. K. Seki, S. Nishihara, and S. Masuda, Microbial. Immunol., 29, 559 (1985). 